Boise State University

ScholarWorks

Literacy, Language, and Culture Faculty

Publications and Presentations

Department of Literacy, Language, and Culture

$1-1-2009$

\title{
VideoPoetry: Integrating Video, Poetry and History in the Classroom
}

James Armstrong

Boise State University

Peter Lutze

Boise State University

Laura Woodworth-Ney

Idaho State University 


\title{
VideoPoetry: Integrating Video, Poetry and History in the Classroom
}

\author{
James Armstrong, Boise State University, Idaho, USA \\ Peter Lutze, Boise State University, Idaho, USA \\ Laura Woodworth-Ney, Idaho State University, Idaho, USA
}

\begin{abstract}
VideoPoetry integrates video and poetry to explore historical or geographic subjects. VideoPoetry is both a process and a product. This paper will use a short VideoPoem, "Mary Hallock Foote at Stone House," to demonstrate how students of all educational levels can become engaged in creating VideoPoetry. Each VideoPoem offers students a cross-disciplinary experience that involves research, analysis of information, imaginative writing and video composition leading to a classroom presentation of the final product. As a process VideoPoetry requires the investigation of a subject, in this case, Mary Hallock Foote, artist and illustrator of the Western United States. Based on the historical research including her published reminiscences, one of the authors wrote a narrative poem imagining Foote's reflections on her life at Stone House. The poem evoked mental images which we brought into the video through historical photographs, Foote's woodblock drawings and present-day video footage of the landscape. Spoken by a woman narrator, the poem along with appropriate sound effects became the soundtrack and structuring element for the VideoPoem. Preceding the VideoPoem is an introduction which uses an objective voice to establish the historical context. As a product, this VideoPoem expresses an interpretation of the life and thoughts of an historical person and the place where she lived. The pictures both illustrate the poem and extend its evocative quality. As such "Mary Hallock Foote at Stone House" is an example of Imaginative Writing, an instructional strategy that encourages students to use their imaginations to create valid contexts in which historical figures lived and acted. For viewers, VideoPoetry conveys both historical information and a sense of what it was like to live in another era. VideoPoetry expands the possibilities of studying history by providing a multi-media and multi-sensory experience.
\end{abstract}

Keywords: Digital Media Arts and Education, Creative Arts in the Humanities, Video, Poetry, Cross-disciplinary Projects, Interdisciplinary Projects

$\mathrm{V}$

IDEOPOETRY OFFERS A new model for a collaborative classroom project, in which students create a video based on two or more content disciplines. This model has three stages: students research a topic, compose an imaginative interpretation of their research, and present this interpretation in a video. We envision this as a collaborative project carried out in groups of three or four students and possibly involving two or more classroom teachers. This paper includes two major sections which provide an overview of the process of creating a VideoPoetry project: Planning a VideoPoetry Project; and A Prototype Project: Mary Hallock Foote at Stone House.

Our prototype project involves history and poetry. Instead of history any other content discipline can be used, provided it includes a research component. Similarly, a prose narrative can be substituted for a poetic narrative, provided that the viewpoint of the narration presents an imaginative interpretation of the research data, through the imagined voice of a contemporary or historical person. This narrative expresses a unique personal viewpoint consistent with factual information and can be delivered in the first or third person.
This VideoPoetry project grows out of an educational strategy called Imaginative Writing. In Imaginative Writing, as described by literacy educators Readence, Bean, and Baldwin (2001), students imagine the viewpoint, experience and feelings of someone who lived in a past time and place. Based on historical research the students create an interpretation from the historical person's perspective in the form of a fictional diary, news article, letter, poem, or some other written document. Finally, students can present their imaginative texts in media other than the printed page - for example, video presentation, poster or a PowerPoint slideshow, which may involve music, dance, drama, and other visual arts.

Such Imaginative Writing assignments encourage students to develop an understanding of and empathy for historical people and their experiences in a particular place (Loffer, 1998). Richardson suggests that researchers use poetry and other literary forms as "evocative representations," which "re-create lived experiences and evoke emotional responses" (1994, p. 521). Composing an Imaginative Writing also involves students in using the intellectual tools of more than one discipline, such as history and fiction. To accomplish this work, the student-artist must learn about the possibilities and constraints of a medium 
of expression and "to think within a medium" (Eisner, 2002b, p. 13).

Projects that involve students in producing Imaginative Writing or evocative representations in literary genres, visual arts, or music also may increase students' motivation. Creating an imaginative response produces "aesthetic satisfaction," which grows from the challenge of the work as well as the maker's "idea which the work embodies" (Eisner, 2002b, p. 14). According to Renzulli, Leppien, and Hays, "Imagination is the key to motivation" (2000, p. 11).

Finally, cross-disciplinary projects based on artistic and literary responses to historical information can motivate students to reclaim the past and encourage them to become lifelong learners in the disciplines we teach. As Eisner states, "it is the aesthetic that provides the natural high and contributes the energy we need to want to pursue an activity again and again" (2002a, p. 582).

\section{Planning a VideoPoetry Project}

Student VideoPoetry projects can be very satisfying, to both teachers and students, but such projects are complex and require careful planning to be successful. VideoPoetry projects also involve a range of skills not usually required for research papers: writing poetry or prose narratives, finding or creating visual images to accompany the narrative, and video shooting and editing. Teachers must first assess student skill levels and ability to work in collaborative groups. Students may need appropriate instruction and specific project constraints to be successful. Even so, student engagement in one or more content disciplines and expressive media makes a VideoPoetry project a rich learning experience. The final product is more accessible than a traditional research paper and engages a wider audience of classmates, parents and others.

The following planning considerations and materials are intended as a foundation for teachers to start their students in VideoPoetry projects. Although we want to provide a useful foundation, the scope of this paper is not as thoroughly detailed as a handbook might be. Rather, this paper is a point of departure providing commentary on some of the most salient points and leaving other considerations to the needs and objectives of the individual teacher.

\section{Preliminary Considerations}

Before embarking on VideoPoetry project assignments, teachers might find it useful to consider a range of factors that affect the plausibility and nature of the assignment. The following list represents some of these global issues that must be addressed:

1. Maturity of students for conducting collaborative, semi-autonomous work.

2. Availability of video equipment, or other audiovisual production and presentation equipment.

3. Teacher's knowledge of technological equipment.

4. Teacher's experience in guiding student writing.

5. Availability of teacher planning time.

Once these global issues have been addressed favorably, then the teacher can consider factors related to the specific course in which a VideoPoetry project might be assigned. Some of these factors include the following:

1. Possible collaboration with other teachers and their students. (See Appendix A VideoPoetry Project Planning Template.)

2. Aspects of curriculum that lend themselves to research.

3. Aspects of curriculum that lend themselves to Imaginative Writing or other evocative representation.

4. Amount of class time and emphasis appropriate for the study of the subject area of the curriculum addressed by the video project.

5. Amount of time students will be expected to work on project outside of class.

\section{Once the Project's Subject Area has been Chosen}

1. Determine the degree of student choice for a specific project topic. Considering some of the global issues listed earlier, such as student maturity and ability to carry out semi-autonomous work, teachers can determine how much to constrain or widen student choice. For example, in a project on Nobel Prize winning authors, may students choose any prize winner or must they pick one from a teacher-made list? In the area of research sources, does the teacher provide a list of acceptable Internet sites or do students browse the Web in order to find their sources? See Figure 1. 


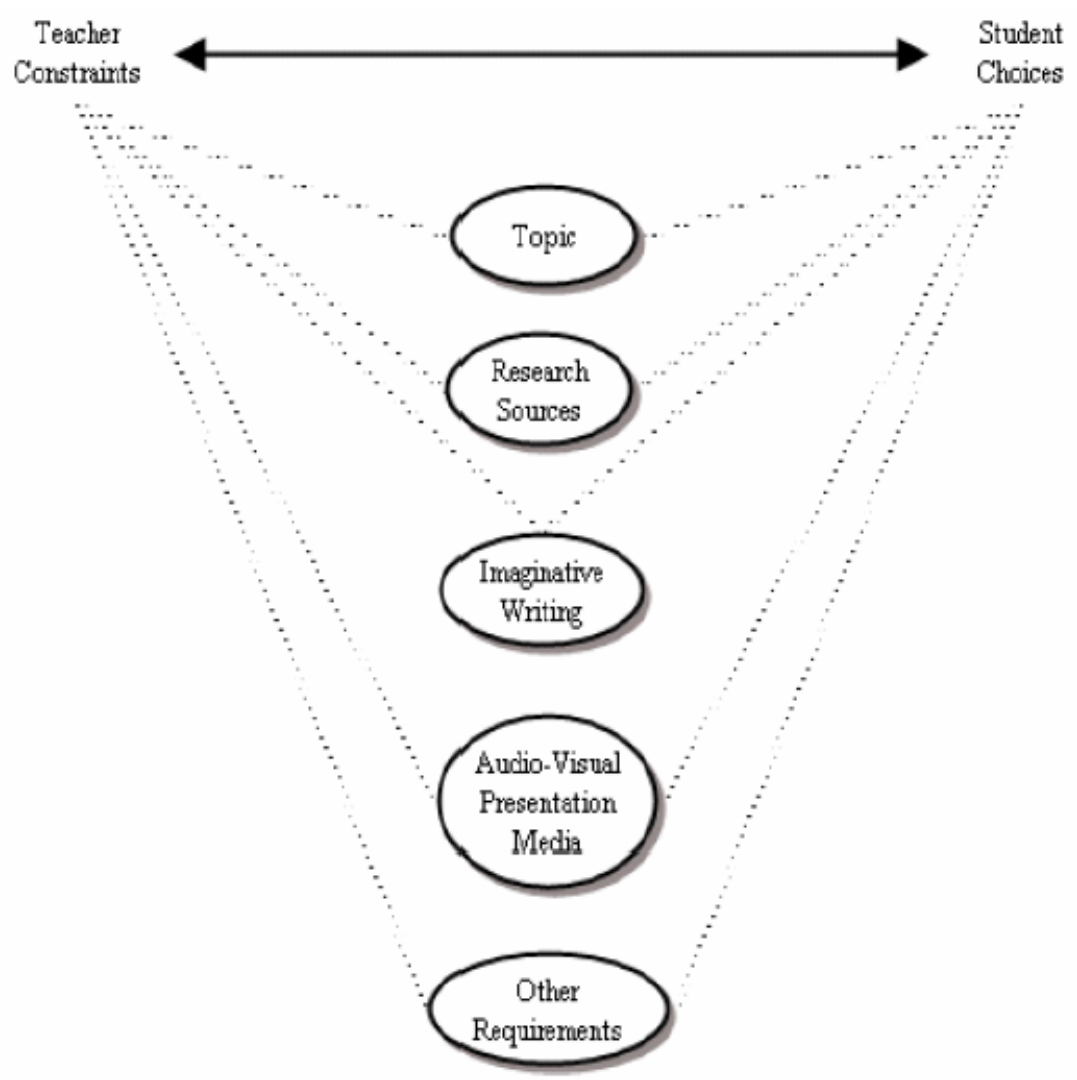

Figure 1: Teacher Constraints and Student Choices. Dotted lines indicate a continuum of teacher and student ownership on VideoPoetry components

2. Provide student guidelines for project (see Appendix B for guidelines and related suggestions).

3. Provide students with technical instruction if necessary (such as video editing).

4. Determine the composition of the groups (how many students per group? will students be grouped according to interests? skills or knowledge? prior relationships? motivation? sense of responsibility?).

5. Schedule class time for students to work on and present their projects (compose, edit, present rough stages, etc.).

\section{A Prototype Project: Mary Hallock Foote at Stone House}

The purpose of our VideoPoetry project, Mary Hallock Foote at Stone House, is to evoke a sense of what life was like for one of Idaho's earliest literary and artistic figures. From 1884 to 1895, Mary Hallock Foote lived in the Boise area. Raised and educated in New York, this Victorian gentlewoman confronted a radically different landscape and way of life in Idaho Territory. Unlike many pioneer women in Idaho whose stories have not survived, Foote has left a legacy of drawings and stories that provide unique historical insights. She saw the West with fresh eyes and left a record in her art and writings of what she experienced here. For these reasons we chose Mary Hallock Foote as the topic of our VideoPoem. As professors living in Idaho, the three of us brought three academic backgrounds and perspectives to this collaborative project: history, poetry, and videography. Our individual contributions in creating this project are discussed later in the paper.

The Subject Content emphasizes the four years during which Mary Hallock Foote lived in a house overlooking the Boise River about ten miles upstream from Boise City. Removed from Eastern society, her life in the Far West focused on tending to the needs of her family as well as writing and drawing. The opening of the VideoPoem imagines Mary watching her young daughter wading in the shallow stream near their house. This prompts Mary to recall her arrival in the Boise area and her first impressions. She continues to reminisce about her family life in the Stone House, which her engineer-husband had built, and her experiences venturing into the canyon lands near their home. By viewing her drawings and the videography of the current canyon landscape, the audience can see her world through her eyes.

We wrote the previous two paragraphs in the form of the introductory part of a "Project Summary Report" (please see Appendix B). 


\section{Creating the Project}

Our three-stage VideoPoetry Project began with accessing historical information about Mary Hallock Foote. The poet began by reading Foote's $A$ Victorian Gentlewoman in the Far West: The Reminiscences of Mary Hallock Foote (1972). Later, the historian supplemented this source with information from other historical documents, including Mary Hallock Foote's letters, manuscripts, and fiction. A summary of information relevant to the VideoPoem's focus appears in the next section, "History: Mary Hallock Foote." Then comes the second stage of creating the project: the poet's process of responding imaginatively to the historical information about Mary Hallock Foote. The final section, "Video: Imaging Poetry, History and Landscape," details the integration of the narrated poetry with visual images, including Foote's drawings, historical photographs and contemporary videography.

\section{History: Mary Hallock Foote (Laura Woodworth-Ney)}

As an historian, I provided the following summary of my research into the life of Mary Hallock Foote. Being aware of the focus of the poem and the video, I narrowed my summary to her life in Idaho.

When Mary Hallock Foote stepped off of the Oregon Short Line Railroad platform at Kuna, Idaho Territory, in 1884, she was already a well-established illustrator. Kuna-located fifteen miles south of Boise in a sea of sagebrush - was the nearest railway stop to the family's destination in the Boise River Canyon, where her husband Arthur Foote attempted to build an irrigation project in the 1880 s and early 1890s. The 1880 U.S. Census found 1,899 people living in Boise City, and only 32,610 living in all of Idaho Territory.

If Mary Hallock Foote's fame was unusual, her circumstances were not. Her trip to Idaho represented the mobility of many educated, eastern-born Americans in the $19^{\text {th }}$-century. Mary Hallock was born in 1847 and raised in a Quaker family in Milton, New York. At sixteen she left her family home for the Cooper Union School of Design in New York City, one of the rare places in North America devoted to the arts education of women.

Arthur Foote completed almost two years of study at the Sheffield Scientific School at Yale University. He married Mary Hallock in 1876, and they immediately traveled to the Far West, where mining and irrigation projects promised opportunity for Arthur's engineering ambitions. Mary, known as "Molly" to her friends and family, followed Arthur's meandering career from one hastily built western community to another: New Almaden, California; Leadville, Colorado; Morelia, Mexico; and Boise Valley, Idaho Territory. The couple finally settled down for good at Grass Valley, California, in 1896.

In mining town cabins, stage coaches, trains, and between the births of three babies, Mary Hallock Foote drew the illustrations of her surroundings that would come to define her career. At the prompting of her editor and friend, Richard Watson Gilder at The Century Illustrated Monthly Magazine, she also started to write local color stories. Throughout the 1880 s and into the twentieth century, Foote's colorful writings of western life reached The Century Magazine's 220,000 monthly readers (Miller, 2002, p. 99).

It was through her eye for the poetic in every day life and her lyrical, descriptive style that Foote established her own reputation. Writing of Foote's illustration, "Looking for Camp," Foote's biographer states, "Details of the man's clothing, his riding gear, and the grassy hillside make this an authentic picture; suggestions of the man's dignity, the solemnity of the landscape, and the motion of the figures make it poetic" (Miller, 2002, p. 113; see Figure 2).

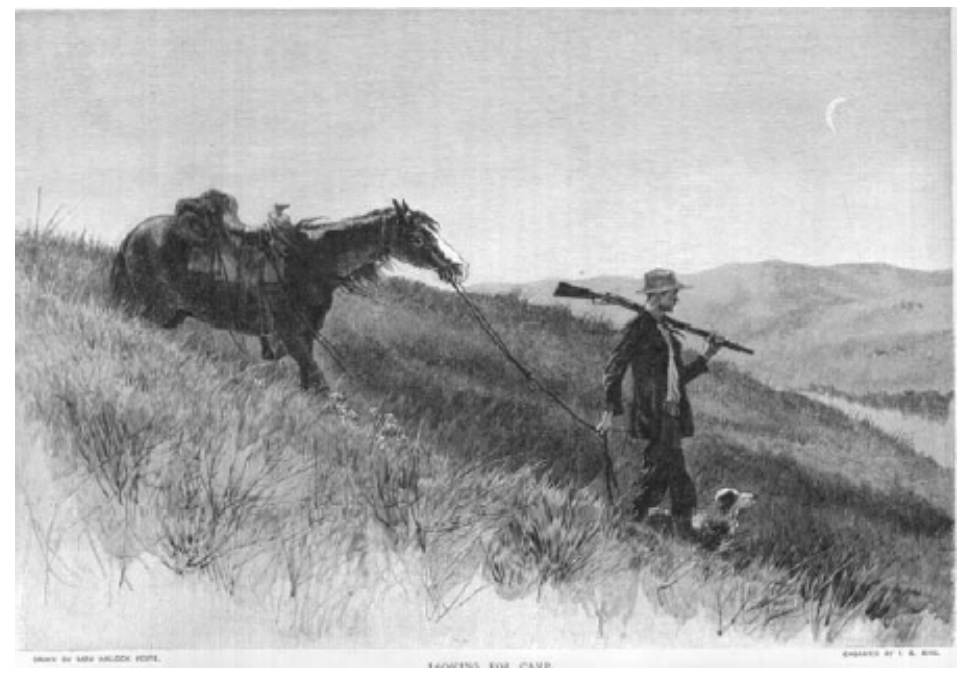

Figure 2: “Looking for Camp.” The Century Monthly Illustrated Magazine (November 1888-April 1889) 
Foote's novel John Bodewin's Testimony, first serialized in The Century Magazine in 1885, paid for the striking stone house the Footes built on a shelf of the Boise Canyon. Foote's pen and her drawing materials became the source of the family's income as Arthur's irrigation project faltered under heavy expenses, reluctant eastern investors, and engineering challenges. While in Idaho, Mary Hallock Foote produced three novels, The Last Assembly Ball in 1889; The Chosen Valley in 1892; and Coeur d'Alene in 1894; and many short stories, including two collections, In Exile and Other Stories and The Cup of Trembling and Other Stories. By the time the couple left Boise for mining opportunities at Grass Valley, California, Foote had become, in the words of her biographer, "the best-known woman writer and illustrator of the American West" (Miller, 2002, p. 93).

\section{Poetry: Imagining the Interpretation of Historical Information (James Armstrong)}

Upon reading Mary Hallock Foote's A Victorian Gentlewoman in the Far West (Foote, 1972), I wanted to write a poem about the challenges she faced as a cultured eastern woman who became the wife of an engineer in the Far West of the United States. She managed to take care of her family and maintain her career as a writer and illustrator. In the poem, I wanted to reveal the essence of Foote's life in the Boise area and what her illustrations conveyed to me. I also had in mind that a VideoPoetry version of the poem would require images to represent what I'd written or implied in the poem.

In the Idaho State Historical Society Library, I found a photograph of Foote standing with her two oldest children (Figure 3).

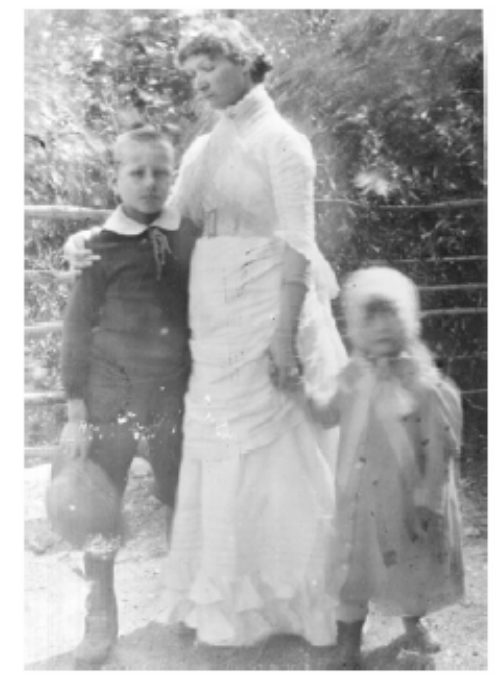

Figure 3: Mary Hallock Foote with Son Arthur Jr. and Daughter Betty. This photograph is reproduced with permission of The Idaho State Historical Society (ISHS No. 2505)

This image came to mind when I sat beside the shallow stream behind the Stone House site and listened to the water pour through the smooth rocks. From the historical photograph, I could imagine Foote holding the hand of young Betty as she waded in the cool water of Lydle's Gulch. This is where my poem began, "Late spring — stream sounds move you/ Back through time, your Agnes now the same age/ As little Betty, who waded here that first year" (see Appendix C, lines 1-3). A few weeks after I wrote the poem, Peter and I returned to shoot video of the stream and to record its sounds. These images and her Reminiscences prompted me to imagine how Foote might have reflected on her life at the time: "Bubbles playing upon the roiling surface/ Release your thoughts to your artist's eye./ Memory and imagination meet/ Where murmurs of the muse flow through your hand" (Appendix C, lines 11-14; see also Figure 4). 


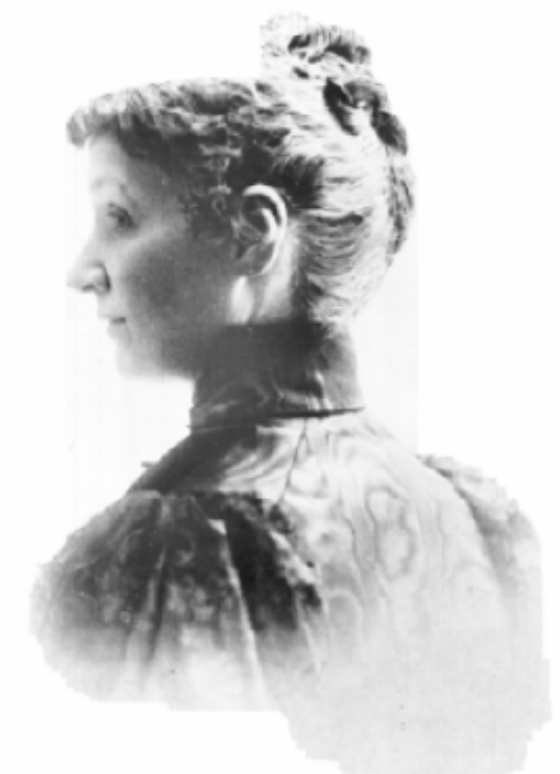

Figure 4: Mary Hallock Foote. This photograph is reproduced with permission of The Idaho State Historical Society (ISHS No. 63-338.12)

Another historical photograph, taken by Foote, shows a newly built Stone House with young Betty on the porch and snow on the ground (see Figure 5). Among Boise State library's holdings of The Century Magazine, I found the issue containing Part I of her novel, John Bodewin's Testimony. The historical photograph and a scanned image of the magazine's title page appears in the VideoPoem: "You moved in for Christmas of ' 85 ; / Your story in Century paid the bills" (Appendix C, lines 34-35).

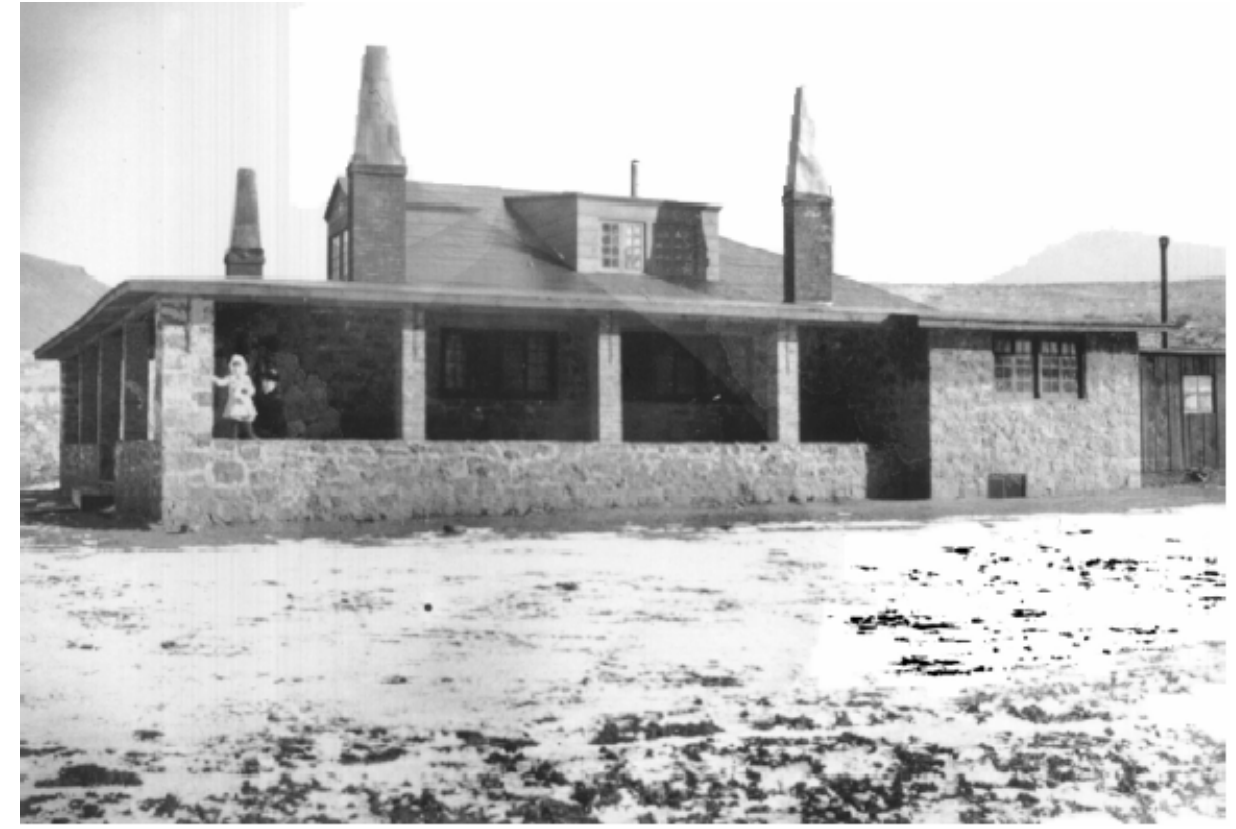

Figure 5: The Footes' Stone House in the Boise River Canyon. This photograph is reproduced with permission of The Idaho State Historical Society (ISHS No. 2505-A)

A Foote illustration, which appears in The Century Magazine's serialized version of her novel The Chosen Valley, shows a young woman standing and reading in front of a window (Foote, 1892). Framed in the window is a view from the Footes' house looking downriver in the Boise Canyon (see Figure 6). The basalt canyon walls in the distance look the same as they do today from the Footes' house site. This view dominated the Footes' westward view during the years they lived in the Boise Canyon: "That V-shape in the notch where the river went out and the sunset looked in bounded our world toward the valley" (Foote, 1972, p. 295). 
THE CHOSEN VALLEY. ${ }^{1}-\mathrm{V}$.

Bv Maky Hallock Footr,

Author of "The Led. Herae Claim," "John Bodesin's Teutinany," etc.

WITH PICTURES BY TIB AUTHOR.

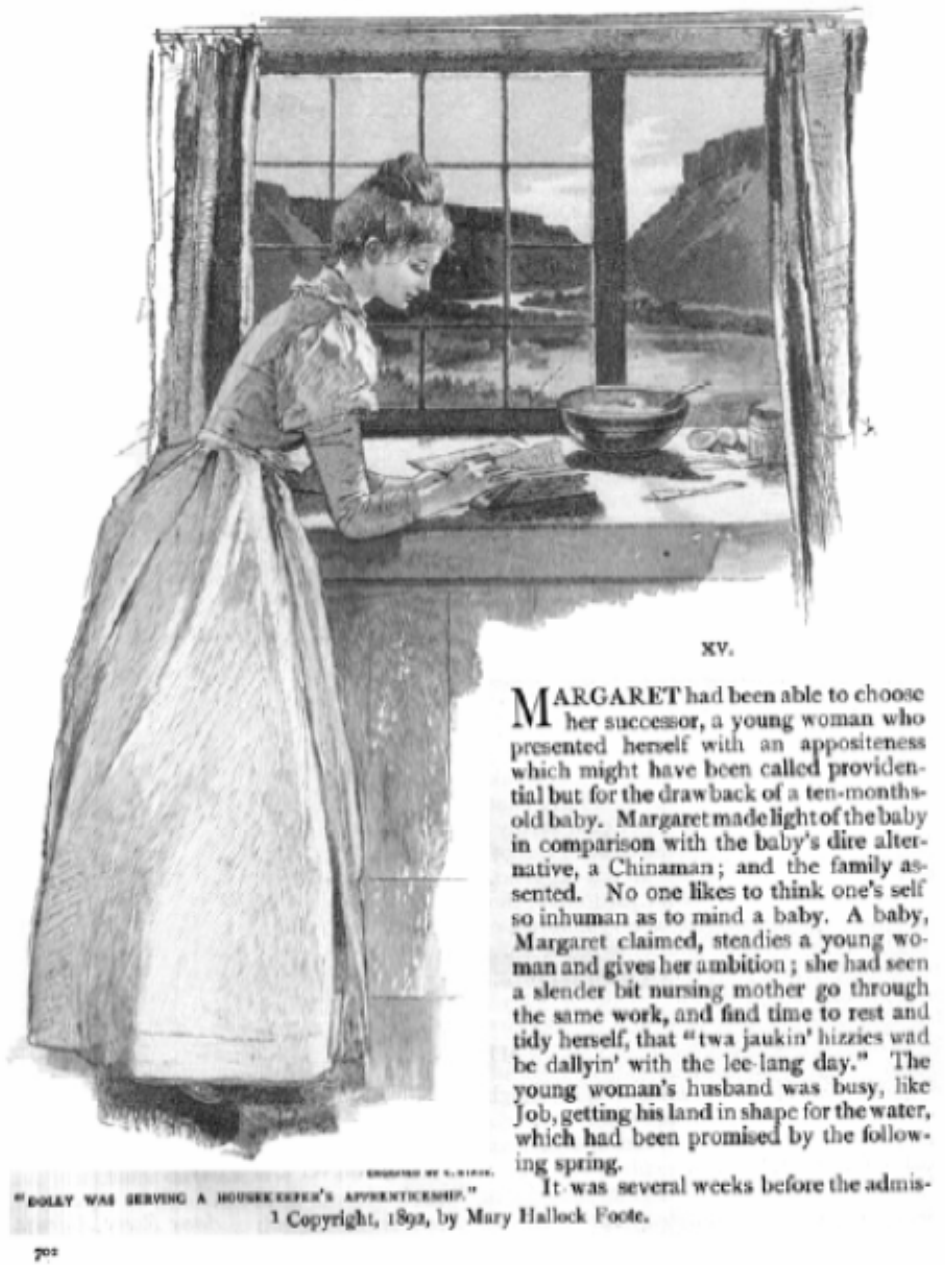

Figure 6: "Dolly Was Serving a Housekeeper's Apprenticeship." The Century Illustrated Monthly Magazine

(April-November, 1892). The opening page of Part V of Foote's novel, The Chosen Valley

In the editing stage of the VideoPoem, I sometimes needed to revise parts of the poem to make it more compatible with sequencing the video. For example, consider these lines: "On other days you ride up through the notch/ Past lapsing water to the canyon rim." The "notch" in the canyon rim is mentioned before the "water" at the river shore - the reverse order from the way she and her husband would have ridden. I revised the poem so that the verbal sequence would correspond to the video tilting up from river shore to canyon rim: "On other days you ride past the river/ Up through the notch to the canyon rim" (Appendix C, lines 69-70).

Foote's experiences as revealed in her writings and illustrations inspired me to write the poem. The visual images and sound effects available for the VideoPoem shaped the content of the poem. Finally, editing the video led to minor revisions of the poetry so that the text of the poem corresponded with the audio-visual elements of the video.

\section{Video: Imaging Poetry, History and Landscape (Peter Lutze)}

The imaginative process of turning historical research into evocative writing in the form of a poem is a largely solitary endeavor. However, the final stage of creating a VideoPoem is very collaborative. The poem provides a general template or roadmap to the video (as well as much of the soundtrack), but is only the starting point for this "imaging" process. While the poet had images in his head when writing the poem, the video collaboration process constrains, reshapes and expands these visions. Some pre-visioned images cannot be found, some cannot be created, some do not work and sometimes new, more 
powerful or effective images emerge from the collaboration.

Our first step in creating the video was to compile a short list of potential images that would work with the voice-over. These were divided into three categories: old photographs that were roughly contemporary to Mary Hallock Foote's period of residence in Idaho; Foote's drawings from the Idaho period; and images that needed to be videotaped (e.g., the view from the Foote Stone House site; plants, animals and other natural phenomena that she would have experienced in the Boise River canyon). Many old photographs were available on the Internet, often from public institutions such as the U.S. Bureau of Reclamation, the Library of Congress and other libraries and archives. Foote's drawings were available from The Century Magazine. Videotaping was done largely in the environs of Stone House. Since the poem had references to different seasons and times of day, we had to adjust our shooting schedules to coincide.

After completing the videography and finding the other images, our next step in creating a video was to find a narrator to record the poem as a voice-over narration. In this case we chose as narrator a woman who is a native-born Idahoan. Since the poem was written in the second person, we did not need to find someone with a New York state accent. First person poems, in contrast, would have less latitude of choice. During recording, some textual changes to the poem were made to facilitate oral reading. The narration needed to be paced slowly enough for audio clarity, to allow cutting between phrases or sentences if necessary, and to allow the viewer to grasp the content and meaning of the images. This first recording is really a scratch track, and may have to be recorded again after the picture has been edited to accommodate minor changes in the poem dictated by the picture editing.

During the editing process, we laid down the voice-over track first. Timing the pictures to the audio was one of the biggest challenges. Sometimes we had to invent or find additional images; in other instances we needed to stretch the audio by inserting pauses, especially when the poem contained lists or several different images in one sentence. To enliven old still photos, we used motion effects to create zooms, pans and tilts. On the audio track, we kept natural sound wherever possible; however, with stills we had no sync sound, and on video footage the original sync sound was often unusable due to the noise of cars, airplanes and other anachronistic sounds. Sound effects were used to enhance or replace sync sound. On this VideoPoem we chose not to add music, but on other VideoPoems we have worked with local composers who created a score for the video. The last stages of the editing process involved fine tuning both the picture and sound to deliver the desired impact on the audience.

\section{Conclusion}

The VideoPoetry process presents a distinctive model for integrating a variety of skills, contentsubject areas and experiences in one creative project. In this multi-stage project students are called upon to work collaboratively in researching a topic, distilling relevant information, and composing a creative response using poetry, video and sound. The final presentation of their project to an audience of peers, parents and teachers involves planning and carrying out a public performance. In this performance students need to reflect on the process and intent of their project in order to introduce it to the audience. This introduction requires them to speak briefly about the essence of their work. The entire process thus engages students in a subject that interests them; thus they are involved on emotional, intellectual, aesthetic and imaginative levels. At the same time they develop their abilities to communicate effectively oral, written and visual media. A successful project, which involves careful planning and coaching by the teacher, culminates in a deep sense of accomplishment by students and teachers. This extensive involvement in a creative research project is likely to develop in students a lasting bond with the researched subject and an ongoing excitement about discovering new information and creating new knowledge.

\section{References}

Eisner, E. (2002a). The kind of schools we need. Phi Delta Kappan, 83(8), 576-583.

Eisner, E. (2002b). What can education learn from the arts about the practice of education? Journal of Curriculum and Supervision, 18(1), 4-16.

Foote, M. H. (November 1888-April 1889). "Looking for Camp," The Century Illustrated Monthly Magazine, 37 (New Series Vol. 15), 108-109. First in a series of Foote's illustrations and commentaries, Pictures of the Far West.

Foote, M. H. (April-November, 1892). "Dolly Was Serving a Housekeeper's Apprenticeship," The Century Illustrated Monthly Magazine, 44 (New Series Vol. 22), 702. Illustration in The Chosen Valley, which first appeared as a serialized novel.

Foote, M. H. (1972). A Victorian gentlewoman in the Far West; The reminiscences of Mary Hallock Foote. San Marino, CA: Huntington Library.

Loffer, C. (1998). Using historical fiction to teach Idaho history. Portals 5(2), 29-31.

Miller, D. (2002). Mary Hallock Foote: Author-illustrator of the American West. Norman, OK: University of Oklahoma. 
Readence, J. E., Bean, T. W., \& Baldwin, R. S. (2001). Content area literacy ( th $^{\text {ed. }) . ~ D u b u q u e, ~ I A: ~ K e n d a l l / H u n t . ~}$

Renzulli, J. S., Leppien, J.H., Hays, T. H. (2000). The multiple menu model: A practical guide for developing differentiated curriculum. Mansfield Center, CT: Creative Learning Press.

Richardson. L. (1994). Writing: A method of inquiry. In N. K. Denzin \& Y. S. Lincoln (Eds.), Handbook of qualitative research (pp. 516-529). Thousand Oaks, CA: Sage.

\section{APPENDIX A: VideoPoetry Project Planning Template}

Title of Project:

Primary Task:

Project Goals:

State/National Standards Addressed:

Overview: Participants \& Materials

\begin{tabular}{|l|l|l|}
\hline Course \& Teacher & Research Sources for Student use & $\begin{array}{l}\text { Presentation Resources for Student } \\
\text { use }\end{array}$ \\
\hline & & \\
\hline & & \\
\hline & & \\
\hline
\end{tabular}

Timeline:

\begin{tabular}{|l|l|l|l|}
\hline Week & $\begin{array}{l}\text { Teacher Instruction \& Ma- } \\
\text { terials }\end{array}$ & Student Activities & Assessment \\
\hline 1 & & & \\
\hline 2 & & & \\
\hline 3 & & & \\
\hline 4 & & & \\
\hline
\end{tabular}

Additional Considerations:

\section{APPENDIX B. VideoPoetry Project Student Guidelines with Teacher Notes}

This appendix includes three sample documents which comprise VideoProject guidelines to be distributed to students and discussed with them. "The Student Planning Checklist," the "Self/Group Evaluation" form, and the "VideoPoetry Project Assessment Rubric" are each followed by "Teacher Notes," which elaborate upon the document categories. ("Teacher Notes" aren't intended to be part of the guidelines that are distributed to students.)

To the Student:

The following guidelines provide you with essential information so that you will successfully complete your VideoPoetry project on time. The guidelines and procedures include three key documents: 1) "Student Planning Checklist," 2) "Student Self/Group Evaluation," and 3) “VideoPoetry Project Assessment Rubric."

\section{General Guidelines}

You are expected to work cooperatively with the other members of your project group. This means that everyone in the group does his or her fair share of the work. The "Student Planning Checklist" allows you to divide the project work among the group members and record your progress towards completing your project. Your completed checklist counts 20 points out of 100 possible for the entire project.

A project with many parts rarely goes smoothly all the time or as originally planned. You will need to be in constant communication with other members of your group. This means listening carefully to others and being willing to consider other ways of doing things. Attendance at all group meetings and thoughtful participation 
are essential to your project's success. If everyone pulls together to work on this project, it can be really interesting and a lot of fun. It may be necessary for you to revise your plans from time to time and to ask your teacher questions if you are not sure how to proceed.

\section{Student Planning Checklist}

Group Members:

You are required to complete the checklist below as you work on your project. This is intended to be a helpful guide so that you'll do everything you need to do to complete your project on time.

Meeting as a group, divide the tasks that appear on the following sheet. Try to give everyone a fair share of the work. Once the work gets underway, you may find that some tasks take more or less time than originally planned. Thus it is important to be considerate of other people's time involvement and be willing to make adjustments in how the tasks are assigned.

\begin{tabular}{|c|c|c|c|}
\hline Check Off & Due Date & Task & Group Members Assigned \\
\hline & & $\begin{array}{ll}\text { A. } & \text { Research Sources List } \\
- & 1 . \\
& 2 . \\
& 3 . \\
& 4 .\end{array}$ & $\begin{array}{l}1 . \\
2 . \\
3 . \\
4 .\end{array}$ \\
\hline - & & B. Poem & \\
\hline & & \begin{tabular}{|ll} 
C. & Video \\
1. & Narration \\
2. & Sound Effects \\
3. & Videography \\
4. & Still photographs \\
5. Other visual image sources \\
6. & Editing \\
\end{tabular} & $\begin{array}{l}1 . \\
2 . \\
3 . \\
4 . \\
5 . \\
6 .\end{array}$ \\
\hline & & \begin{tabular}{|l} 
D. \\
Preparation for Presentation \\
1.Draft: Project Summary Report \\
2.Equipment \\
3.Presentation practice session(s)
\end{tabular} & $\begin{array}{l}1 . \\
2 . \\
3 . \quad \text { All }\end{array}$ \\
\hline . & & \begin{tabular}{|ll} 
E. & Presentation Day \\
1. & Project Summary Report \\
2. & Student Self/Group Evaluation (in- \\
dividual) & \\
3. & Equipment \\
4. & Presentation to class
\end{tabular} & $\begin{array}{l}1 . \\
\text { 3. All } \\
4 . \quad \text { All } \\
\end{array}$ \\
\hline
\end{tabular}

Teacher Notes: Each project group completes this checklist collaboratively, not individually. The checklist is a project requirement, which gives due dates for the preliminary project stages and records student progress through five task areas, A-E.

1. Research Sources. Students simply list their sources. They are required to document them later in their "Project Summary Report" (see Task Area D).

2. Poem. One or more students may be involved in composing and editing the poem. Someone else in the group checks it for consistency with research sources.

3. Video. Production requires collaboration in the following areas: recording the video and sound; gathering other images, sound effects and music; and integrating the components in the editing stage. While one student may take the lead, input from others assures the quality of the content and makes everyone accountable for the product. 
4. Preparation for Presentation. Students draft the "Project Summary Report" and document their research sources. A simplified documentation style for less experienced students is as follows:

a. Book: Author, Title, page numbers used in project.

b. Chapter in Edited Book: Chapter Author, "Chapter Title," Editor, Book Title, chapter page numbers.

c. Magazine or Journal Article: Article Author, "Article Title," Magazine or Journal Title, Date of Issue, article page numbers.

d. Internet: URL of Website, starting with http://

Further preparation includes making sure presentation equipment is reserved for use and functions properly. Finally, the entire group carries out one or more practice sessions to rehearse the presentation.

5. Presentation Day. Each group submits the "Project Summary Report" to the teacher. Each student hands in a completed "Self/Group Evaluation."

\section{Student Self/Group Evaluation Form}

Name:

All comments will be strictly confidential. RETURN TO TEACHER ON PRESENTATION DAY.

1. Evaluate your own role in your group in the following areas (be as specific as possible):

a. Level of activity/participation

b. Cooperation with others

c. Creative input

d. Attendance (and promptness) at meetings and other group activities

e. Please describe the tasks assigned to you

f. Quality of your performance on your assigned tasks

2. Evaluate each of the other members of your group, using the same criteria as in \#1:

a. Level of activity/participation

b. Cooperation with others

c. Creative input

d. Attendance (and promptness) at meetings and other group activities

e. Please describe the tasks assigned to him/her

f. Quality of his/her performance on assigned tasks

3. Please comment on your overall thoughts and feelings about:

a. Your VideoPoetry project (how it turned out)

b. Working in your group to create a VideoPoetry project

c. Any other thoughts about this assignment

Teacher Notes: This evaluation asks each student to reflect individually upon his or her own contributions to the project and to comment upon the contributions of the other group members. Students must be aware from the beginning of the project of the kinds of behavior expected of them and valued by their group as well as the teacher. For this reason, the teacher may want to adapt the form collaboratively with the students. This self/group evaluation process can prove valuable to the teacher, not only in understanding the group's dynamics and assessing each student's participation, but also by providing important feedback for future VideoPoetry assignments. 


\section{VideoPoetry Project Assessment Rubric}

Name:

The rubric shows how your work will be evaluated on the VideoPoetry Project.

\begin{tabular}{|c|c|c|c|}
\hline Project Component & Teacher Comments & $\begin{array}{l}\text { Points } \\
\text { Possible } \\
(\mathbf{1 0 0})\end{array}$ & $\begin{array}{l}\text { Points } \\
\text { Earned }\end{array}$ \\
\hline Student Planning Checklist & & 20 & \\
\hline $\begin{array}{l}\text { VideoPoetry Presentation } \\
\text { Artistic Quality__ (20) Originality, Technique } \\
\text { Subject Content_ (20) Inclusion of research inform- } \\
\text { ation }\end{array}$ & & 40 & \\
\hline $\begin{array}{l}\text { Project Summary Report } \\
\text { Project Introduction } \\
\text { Purpose, Content Overview } \\
\text { Quality of Sources } \\
\text { Source Documentation }\end{array}$ & & 30 & \\
\hline Student Self/Group Evaluation & & 10 & \\
\hline
\end{tabular}

\section{Teacher Notes:}

The completed Student Planning Checklist is due on presentation day.

The VideoPoetry Presentation is divided into two parts. Artistic Quality refers to the creativity, imagination and technical skill of both the writing and the audio-visual elements. Factors to consider are the clarity and originality of the writing, images and audio elements, and the impact of their integration on the audience. Subject Content refers to the inclusion of research information and the accuracy of its representation in the poem. Does the content successfully evoke a consistent and convincing point-of-view of the historical person?

The next assessment component, the Project Summary Report has three parts. The Project Introduction includes a brief paragraph on the purpose of the project and, in a separate paragraph, gives an overview of the Subject Content. This introduction can serve as the basis of the group's opening comments prior to showing their video. (Earlier in this paper, the introduction to our VideoPoem on Mary Hallock Foote provides a sample project introduction.) The Quality of Sources and Source Documentation together have equal weight with the Project Introduction, demonstrating to students the importance of their research for their imaginative presentation.

The Self/Group Evaluation is to be completed by each student individually rather than collaboratively.

\section{APPENDIX C: "Mary Hallock Foote at Stone House"}

\section{Text of Poem}

\section{MARY HALLOCK FOOTE AT STONE HOUSE}

Late spring-stream sounds move you
Back through time, your Agnes now the same age
As little Betty, who waded here that first year.
Water sounds pour over oval stones
Above which you hear his intonations
Sluicing down flat-faced angular basalt:
As Arthur explains drainage and divide,
You see steep green hands of Lydle's Gulch.
The water sound, constant rush of earth's breath,
The splash of little notes, then low gurgles,
Bubbles playing upon the roiling surface
Release your thoughts to your artist's eye.
Memory and imagination meet
Where murmurs of the muse flow through your hand.


You recall stepping to the station platform,

The engineer's wife arriving at Kuna

To raise a family in the Far West.

You rode for miles across the sagebrush plain

By livery rig to Boise's frontier streets,

Victorian wife and mother of two.

Before you came West, a river streamed

Through your eastern dreams of darkest Idaho,

Lonely river dashing against itself.

Water-what brought your Arthur to this place,

His irrigation dream and unfunded scheme

You called "Between the Desert and the Sown."

Water flowing through his canal

Would bring forth fruit from the desert.

Up the Boise River ten miles from town

He built Stone House from fallen canyon walls.

With corner pillars rooted in the hill

And sloping roof extending its round crown,

Your home seems grown out of the knoll.

You moved in for Christmas of ' 85 ;

Your story in Century paid the bills.

Inside, windows open your heart east and west

To Arthur's chosen valley where you dwell-

Managing the cook, governess and nurse,

Being with your children, and giving birth.

The wrap-around porch seats a serenade

Or cradles a nap on a warm afternoon,

Your daughter's respite from lessons and tasks.

You stand at the windbreak, within the reach

Of home and the frontier's indifferent power.

Winter sets you apart: a freighter plies

The stage-road, its teamster on his last trip in

Supplying settlers; then winter cuts them off.

A robin's orange arrival brings you spring:

Bitter sagebrush tinges the dry air, but

The creek whispers sweet-scented syringa.

You walk between columns of locust trees,

Those hardy easterners with sinewy bark.

You gaze into clusters of white blossoms

Cascading you with poignant fragrances

Of moonlit strolls through the woods of your youth

With poets whose "sonnets were born over night,

Like roses in the garden," you say to yourself,

Unlike hills winking wild roses, pink, white, pink,

Or desert moon staring down sage-tinted slopes. 
On special days you cinch up, ride with Arthur Toward Idaho City, into the hills.

So many men without women pass by, So many men without family here

Prospectors, miners, cowboys, and drifters, Looking for silver or something else to take.

But you see warm-bosomed slopes

In the hill country, restful places

Traversed by restless men heading somewhere.

On other days you ride past the river

Up through the notch to the canyon rim

Where treeless plain meets infinite sky.

Each illustration leads the eye beyond

A vanishing point to empty background

Evoking barren desert distances.

Yet your bold lines return the viewer's eye

To river canyon cliffs, to curving hills

Where your drawings people this lonely land

To make the struggles possible to bear.

\section{About the Authors}

\section{Dr. James Armstrong}

Jamie Armstrong is a professor in the Department of Literacy at Boise State University where he teaches courses in reading education as well as reading and study strategies. He has written two textbooks, Reading Tools for College Study and Patterns and Connections, and two books of poetry, Landscapes of Epiphany and Moon Haiku. Jamie collaborated with Peter Lutze on a previous VideoPoetry project: Mountain Seasons.

\section{Dr. Peter Lutze}

Peter Lutze grew up in Oklahoma where his father served as pastor to black parishes. After graduating from Valparaiso University, he obtained an M.F.A. in Filmmaking and a J.D. at the University of Wisconsin, where he also completed his doctoral dissertation on the German film director and social theorist, Alexander Kluge. Since 1990 he has taught at Boise State University, where he has also served as Director of University Television Productions. He was a founder and served for several years as Chair of Treasure Valley Public Access Television. He has produced numerous films and videos.

\section{Dr. Laura Woodworth-Ney}

Laura Woodworth-Ney is an associate professor of history and former co-director of women's studies at Idaho State University. She currently serves as Chair of the Department of History. Dr. Woodworth-Ney is also editor of the state history journal Idaho Yesterdays and is author of the book Mapping Identity: The Creation of the Coeur d'Alene Indian Reservation, 1805-1902 (University Press of Colorado, 2004). 
EDITORS

Mary Kalantzis, University of Illinois, Urbana-Champaign, USA.

Bill Cope, University of Illinois, Urbana-Champaign, USA.

\section{EDITORIAL ADVISORY BOARD}

Robyn Archer, Australia.

Mark Bauerlein, National Endowment for the Arts.

Tressa Berman, BorderZone Arts, Inc., San Francisco and Melbourne, University of Technology, Sydney (UTS), Australia and San Francisco Art Institute, USA.

Judy Chicago, New Mexico, USA.

Nina Czegledy, University of Toronto and Concordia University, Montreal, Canada.

James Early, Smithsonian Institution, Anacostia Museum Center for African American History, USA.

Mehdi Faridzadeh, International Society for Iranian Culture (ISIC), New York and Tehran, Iran.

Jennifer Herd, Queensland College of Art, Griffith University, Brisbane, Australia.

Fred Ho, New York, USA.

Andrew Jacubowicz, University of Technology, Sydney, Australia.

Gerald McMaster, Toronto, Art Gallery of Ontario, Canada.

Mario Minichiello, Loughborough University School of Art and Design, UK.

Fred Myers, Department of Anthropology, New York University, USA.

Darcy Nicholas, Porirua City Council, Pataka Museum of Arts and Cultures, Aotearoa/New Zealand.

Daniela Reimann, University of Art and Industrial Design, Linz, Austria.

Arthur Sabatini, Arizona State University, USA.

Cima Sedigh, Global Education and Health Alliance, Sacred Heart University in Fairfield, Connecticut, USA.

Peter Sellars, World Cultures Program, University of California, Los Angeles, USA.

Ella Shohat, Departments of Art \& Public Policy, Middle Eastern \& Islamic Studies, New York University, USA.

Judy Spokes, Arts Victoria, Australia.

Tonel (Antonio Eligio), University of British Columbia, Canada, and Havana, Cuba.

Marianne Wagner-Simon, Berlin, Germany.

Please visit the Journal website at http://www.Arts-Journal.com for further information about the Journal or to subscribe. 


\title{
THE UNIVERSITY PRESS JOURNALS
}

\author{
International Journal of the Arts in Society \\ Creates a space for dialogue on innovative theories and practices in the arts, and their inter-relationships with society. \\ ISSN: 1833-1866 \\ http://www.Arts-Journal.com
}

International Journal of the Book

Explores the past, present and future of books, publishing, libraries, information, literacy and learning in the information society. ISSN: 1447-9567

http://www.Book-Journal.com

Design Principles and Practices: An International Journal

Examines the meaning and purpose of 'design' while also speaking in grounded ways about the task of design and the use of designed artefacts and processes. ISSN: 1833-1874 http://www.Design-Journal.com

International Journal of Diversity in Organisations, Communities and Nations

Provides a forum for discussion and builds a body of knowledge on the forms and dynamics of difference and diversity. ISSN: $1447-9583$ http://www.Diversity-Journal.com

International Journal of Environmental, Cultural, Economic and Social Sustainability

Draws from the various fields and perspectives through which we can address fundamental questions of sustainability. ISSN: 1832-2077

http://www.Sustainability-Journal.com

Global Studies Journal

Maps and interprets new trends and patterns in globalization. ISSN 1835-4432 http://www.GlobalStudiesJournal.com

International Journal of the Humanities

Discusses the role of the humanities in contemplating the future and the human, in an era otherwise dominated by scientific, technical and economic rationalisms. ISSN: 1447-9559 http://www. Humanities-Journal.com

International Journal of the Inclusive Museum

Addresses the key question: How can the institution of the museum become more inclusive? ISSN 1835-2014 http://www.Museum-Journal.com

International Journal of Interdisciplinary Social Sciences

Discusses disciplinary and interdisciplinary approaches to knowledge creation within and across the various social sciences and between the social, natural and applied sciences.

ISSN: 1833-1882

http://www.Socialsciences-Journal.com

International Journal of Knowledge, Culture and Change Management

Creates a space for discussion of the nature and future of organisations, in all their forms and manifestations.

ISSN: $1447-9575$

http://www.Management-Journal.com

International Journal of Learning

Sets out to foster inquiry, invite dialogue and build a body of knowledge on the nature and future of learning. ISSN: 1447-9540

http://www.Learning-Journal.com

International Journal of Technology, Knowledge and Society

Focuses on a range of critically important themes in the various fields that address the complex and subtle relationships between technology, knowledge and society. ISSN: 1832-3669 http://www.Technology-Journal.com

Journal of the World Universities Forum

Explores the meaning and purpose of the academy in times of striking social transformation. ISSN 1835-2030

http://www.Universities-Journal.com

\author{
FOR SUBSCRIPTION INFORMATION, PLEASE CONTACT \\ subscriptions@commonground.com.au
}

